\title{
Obituary
}

HORMONE

RESEARCH IN

PAEDIATRICS
Horm Res Paediatr 2019;91:290-291

DOI: 10.1159/000499326
Published online: June 25, 2019

\section{Remembering Jean-Pierre Bourguignon, MD, PhD}

Our mentor and colleague, Prof. Jean-Pierre Bourguignon, University of Liège, died on January 30, 2019, less than 2 years after he had been diagnosed with cancer, leaving a stark void in the world of international endocrinology.

Jean-Pierre was a pediatric endocrinologist and pioneer in translational research regarding the role the endocrine system has on the brain of children and young adults. His work helped advance the understanding of the hypothalamic control of puberty and led him to receive the 2014 Andrea Prader Prize, the most prestigious award given by the European Society for Pediatric Endocrinology.

In 1974, he received his MD from the University of Liège (Belgium), specializing in pediatric endocrinology. $\mathrm{He}$ obtained his higher education teaching certification from the University of Liège in 1984. His scientific career began under the mentorship of Paul Franchimont. Very early during is medical studies he became interested in neuroendocrinology, and his essential scientific focus was the neuroendocrine control of puberty onset and pulsatility of GnRH neurons in the hypothalamic arcuate nucleus. He performed several research fellowships in Richard Santen's laboratory at Pennsylvania State University. Until his retirement in 2015, he was the head of the Developmental Neuroendocrinology Unit, GIGA-Neurosciences, Liège. The many graduate students, postdoctor-

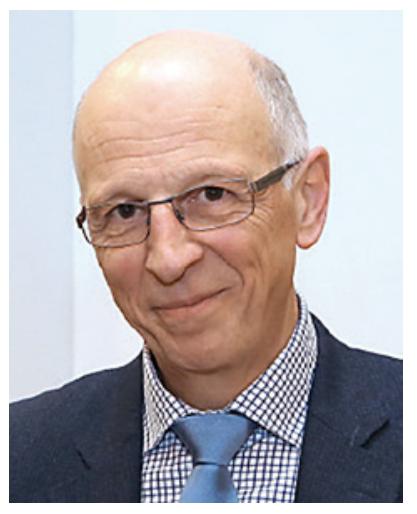

Jean-Pierre Bourguignon, $M D, P h D$

al fellows, and senior researchers who had the chance to work with him will remember his sharp scientific mind, his sense of humor, and his passion for science. He accompanied his collaborators with pedagogy and generosity throughout their development.

Aside from his prominent role in this research field, Jean-Pierre was also an excellent clinician involved in the management of children with growth disorders and type 1 diabetes. Generous and conscious of the difficulties of young chronic patients, he shared with them his passion for hiking during several mountain treks, which became a tradition. 
Another passion of Jean-Pierre's was transmitting knowledge. He initiated the implementation of problembased learning in the Faculty of Medicine in 2000 and became head of the Institute of Training and Research in Higher Education at the University of Liège in 2011. His rare teaching and human qualities have led many of those he mentored to pursue their own rewarding careers in pediatric medicine and science.

$\mathrm{He}$ and his team were among the first to study the role of endocrine-disrupting chemicals (EDCs) on puberty onset and trends in puberty disorders. During the last years before his retirement as chief of pediatric endocrinology, University of Liège, EDCs became a focus of his research group and made a significant impact around the world. His research background, which included both solid clinical and experimental expertise, helped the group become an international leader in EDC research.

Realizing the need to raise awareness about human environmental exposures to EDCs, Jean-Pierre decided that he needed to warn the public as well as various regulatory bodies of these dangers. Specifically, he felt he needed to emphasize the dangers of these compounds on the health and development of children and young adults.

In 2014, he was nominated as co-president of the Endocrine Society's Global Endocrine Disrupting Chemicals Policy Task Force. His contributions received considerable international momentum, leading to him receiving the Endocrine Society's 2016 Outstanding Public Service Laureate Award for Leaders Raising Global Awareness of the Health Effects of Endocrine-Disrupting Chemicals, and he was credited for playing a crucial role in "engaging the European community on EDC science and policy."

As he neared the end of his life, it was with great determination that he worked on his book that would inform everyday citizens about the dangers of endocrine disrupters. As he had done throughout his career, rather than taking the position of an omniscient expert, he sought to motivate others to reflect and ask more questions.

His scientific curiosity and his passion for child health advocacy will be an inspiration for all those who had the opportunity to work with him.

Anne-Simone Parent, Liège

Niels E. Skakkebaek, Copenhagen 